\title{
INVOLVEMENT OF LUTEINIZING HORMONE IN THE IMPLANTATION PROCESS OF THE RAT
}

\author{
H. G. MADHWA RAJ, M. R. SAIRAM AND N. R. MOUDGAL \\ Reproductive Biology Unit, Department of Biochemistry, \\ Indian Institute of Science, Bangalore-12, India
}

(Received 28th November 1967, accepted 26th February 1968)

\begin{abstract}
Summary. The use of specific anti-FsH and anti-LH substances has shown that $\mathbf{L H}$ is the only pituitary gonadotrophin involved in the implantation process. Using different dosages of $\mathbf{L H}$ antiserum at different time intervals, it has been possible to arrive at a minimum effective dose $(0.05 \mathrm{ml})$ which, when given on the 4th day at 10.00 hours, results in inhibition of implantation on the 8th day. We have shown that, at this dose, the antiserum is mainly inhibiting the oestrogen surge. It is proposed that an LH surge precedes an oestrogen surge on Day 4 of pregnancy.
\end{abstract}

\section{INTRODUCTION}

It is well known that the two ovarian steroids, oestrogen and progesterone, produced under the influence of the pituitary, are essential for bringing about implantation of the fertilized ovum in the rat. Using specific antigonadotrophins we have recently reported briefly on the specific involvement of pituitary $\mathbf{L H}$ in the implantation process (Madhwa Raj, Sairam \& Moudgal, 1967).

The present paper gives a detailed account of our work on the mode of action of $L H$ in the implantation of the rat blastocyst.

\section{Hormones}

\section{MATERIALS AND METHODS}

NIH-LH-S9, bovine thyrotrophin (NIH-TSH-B4) and ovine FSH (NIHFSH-s3) used in this study were gifts of the Endocrine Study Section, National Institutes of Health, U.S.A. Oestradiol-17 $\beta$ was purchased from Sigma Chemicals Company, U.S.A. The follicle stimulating hormone inhibitor was extracted and purified from the urine of the bonnet monkey according to the method of Sairam, Madhwa Raj \& Moudgal (1966, 1968). Highly purified ovine prolactin and bovine growth hormone $(\mathrm{GH})$ were gifts from Professor G. H. Li, University of California, San Francisco.

\section{Immunization}

Antiserum to ovine LH was produced in an adult albino female rabbit according to the method of Moudgal \& $\mathrm{Li}$ (1961). The antiserum was suitably 
absorbed with 1:10 diluted normal sheep serum, to remove antibodies for nonspecific serum proteins. The completion of absorption and presence of specific antibodies to LH were confirmed by using the agar gel double diffusion technique, the details of which have been described earlier (Moudgal \& $\mathrm{Li}$, 1961).

\section{Animals and general procedures}

Albino adult female rats of the Institute colony weighing 120 to $160 \mathrm{~g}$ were used. They were mated with males of proven fertility, and the day on which vaginal smears showed the presence of spermatozoa was considered as Day 1 of pregnancy.

The hormones and specific antigonadotrophins were administered by the subcutaneous route. Laparotomies were performed on the 8th and 15th days and autopsy on the 20th day of pregnancy. At each laparotomy the nature and number of implantation sites were noted. At autopsy the ovarian and uterine weights, number of corpora lutea and nature and number of implantation sites or growing foetuses were noted. In some cases the animals were left for the full period of gestation and allowed to litter.

\section{Histology}

Tissues were fixed in Bouin's fluid for $24 \mathrm{hr}$, embedded in paraffin, sectioned to $10 \mu$ thickness and stained with haematoxylin and eosin.

\section{RESULTS}

\section{Immunological characterization of LH antiserum}

The earlier report of Moudgal \& $\mathrm{Li} \mathrm{(1961)} \mathrm{showing} \mathrm{that} \mathrm{antiserum} \mathrm{to} \mathrm{ovine}$ LH cross-reacts with rat pituitary LH was confirmed using both the agar gel double diffusion and biological inhibition test. Ovine LH antiserum has earlier been successfully used to neutralize the physiological effects of LH in the rat, such as spermatogenesis (Hayashida, 1962a) and oestrous cycle (Young, Nasser \& Hayashida, 1963).

The absorbed antiserum to $\mathrm{LH}$, in an Ouchterlony double diffusion test, did not show any cross-reaction with ovine pituitary FSH, prolactin and bovine GH. Bovine TsH, however, showed the presence of an antigen which completely cross-reacted with ovine LH, showing that the TSH preparation used was contaminated with $\mathbf{L H}$ and the antiserum did not contain TSH-specific antibodies (Plate 1). Since antibodies specific to bovine $\mathrm{GH}(\mathrm{Li}$, Moudgal, Trenkle, Bourdel \& Sadri, 1962), ovine prolactin (Hayashida, 1962b) and FSH (Ely, Tuercke \& Chen, 1966) have been shown not to cross-react with the respective hormones of the rat, even the presence of contaminating antibodies in the ovine LH antiserum should not be of any consequence. The absorbed antiserum had approximately 1.2 to $1.5 \mathrm{mg}$ of antibody/ml as determined by the quantitative precipitin test described previously (Moudgal \& Li, 1961).

\section{Biological characterization of FSH inhibitor}

The FSH inhibitor isolated from the monkey urine has been shown to be 
PIATE 1

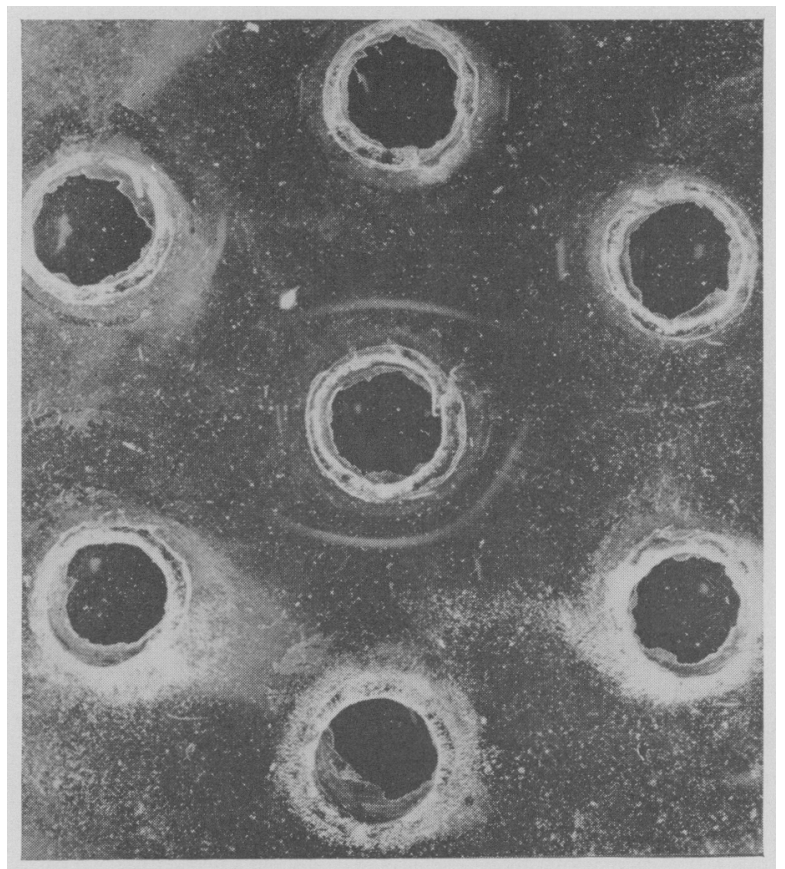

Immunological specificity of $\mathrm{r}$ in antiserum. The central well contained rabbit antiserum to ovine I,H absorbed with normal sheep scrum. The other wells, from the top in clock-wise direction, contained ovine I.H $(30 \mu \mathrm{g})$, bovine (in $(50 \mu \mathrm{g})$, bovine 1 sh $(50 \mu \mathrm{g})$, ovine I.I $(30 \mu \mathrm{g})$, ovine prolactin $(50 \mu \mathrm{g})$ and ovine Fse $(100 \mu \mathrm{g})$.

(Facing $p .336$ ) 
species nonspecific in its action, in that it was able to neutralize the biological activity of FSH from a variety of species including that of the rat (Sairam et al., 1968). The inhibitor, however, does not neutralize LH. Five hundred $\mu \mathrm{g}$ of this inhibitor could neutralize the biological activity of $200 \mu \mathrm{g}$ of NIH-FSH-s3 in the HCG augmentation assay. The total dose of $1.3 \mathrm{mg}$ of inhibitor used in the present investigation was sufficient to inhibit completely the activity of endogenous FSH.

Specificity of $L H$ in initiating implantation

Administration of specific antigonadotrophins, LH antiserum and FSH inhibitor, to pregnant rats from Days 1 to 7 of pregnancy showed that only the former was effective in inhibiting implantation, thus indicating that only $\mathbf{L H}$ was involved in this process (Table 1). Though ovarian weight and number of

TABLE 1

INVOLVEMENT OF LH IN IMPLANTATION

\begin{tabular}{|c|c|c|c|c|c|c|}
\hline Group & Treatment & $\begin{array}{c}\text { No. } \\
\text { of } \\
\text { rats }\end{array}$ & $\begin{array}{l}\text { No. of } \\
\text { rats with } \\
\text { sites }\end{array}$ & $\begin{array}{l}\text { Ave. } \\
\text { no. of } \\
\text { sites }\end{array}$ & $\begin{array}{c}\text { Uterine } \\
\text { weight } \\
\text { (Mean } \pm S . D .)\end{array}$ & $\begin{array}{c}\text { Ovarian } \\
\text { weight } \\
(\text { Mean } \pm S . D .)\end{array}$ \\
\hline I & $\begin{array}{l}\text { Normal rabbit serum } \\
\text { (control) }\end{array}$ & 5 & 5 & $8 \cdot 6$ & $406 \pm 63.4$ & $47.5 \pm 9.08$ \\
\hline II & $\begin{array}{l}\text { Monkey FsH inhibitor* } \\
\text { Total dose: } 1.25 \mathrm{mg}\end{array}$ & 4 & 4 & $10 \cdot 0$ & $472 \pm 63 \cdot 1$ & $50 \cdot 2 \pm 5 \cdot 8$ \\
\hline III & $\begin{array}{l}\text { LH antiserum } \dagger \\
\text { Total dose: } 1.5 \mathrm{ml}\end{array}$ & 5 & 0 & 0 & $97 \cdot 8 \pm 8 \cdot 5$ & $49 \cdot 3 \pm 8 \cdot 9$ \\
\hline
\end{tabular}

* Day 1: $100 \mu \mathrm{g} / \mathrm{rat}$. Dose increased by $25 \mu \mathrm{g}$ every day up to 5 th day. Days 6 and $7: 250$ $\mu \mathrm{g} / \mathrm{rat}$.

$\uparrow$ Days 1 to $3: 0.1 \mathrm{ml} / \mathrm{rat} /$ day; Days 4 to $7: 0.3 \mathrm{ml} / \mathrm{rat} / \mathrm{day}$.

corpora lutea of the control and the LH antiserum-treated groups did not differ significantly, the histological examination of the ovaries revealed that the treated ovaries had smaller corpora lutea with a low degree of luteinization. The luteal cells of the treated group had sparse cytoplasm which was hyaline in nature, pycnotic nuclei and a central non-luteinized area. The interstitium was reduced and non-luteinized, the hilus region being occupied by a highly vascular bed.

\section{Localization of inhibitory action of LH antiserum}

Pilot experiments wherein a single dose of $\mathbf{L H}$ antiserum was given each morning starting from Days 1 to 7 of pregnancy showed that if the antiserum treatment was started after Day 4 of pregnancy, it had no effect on implantation. In order to study the critical time element at which the antiserum was effective, to one group of rats $0.2 \mathrm{ml}$ of antiserum was administered at 10.00 hours on Day 4 of pregnancy and to another the same volume was administered at 18.00 hours on the same day. As can be seen from the results presented in Table 2, administration of antiserum on the evening of the 4th day was not 
effective in inhibiting implantation. It may, however, be noted that, at the second laparotomy, whereas the group receiving the injection in the morning continued to show lack of implantation sites, the 4th-day evening group showed that the 8th-day sites had been secondarily resorbed.

TABLE 2

LOCALIZATION OF INHIBITORY ACTION OF LH ANTISERUM ON IMPLANTATION

\begin{tabular}{c|c|c|c|c|c|c}
\hline Group & Treatment & $\begin{array}{c}\text { No. } \\
\text { of } \\
\text { rats }\end{array}$ & $\begin{array}{c}\text { No. of } \\
\text { rats with } \\
\text { sites }\end{array}$ & $\begin{array}{c}\text { No. of } \\
\text { sites } \\
\text { (total/ave. })\end{array}$ & $\begin{array}{c}\text { No. of } \\
\text { rats with } \\
\text { sites }\end{array}$ & $\begin{array}{c}\text { No. of } \\
\text { sites } \\
\text { (total/ave.) }\end{array}$ \\
\hline I & $\begin{array}{c}\text { 0.2 ml antiserum on } \\
\text { Day 4 at 10.00 hours } \\
0.2 \mathrm{ml} \text { antiserum on } \\
\text { Day 4 at 18.00 hours }\end{array}$ & 5 & 0 & $0 / 0$ & 0 & $0 / 0$ \\
\hline
\end{tabular}

Induction of delayed implantation with a 'minimum effective dose' (MED) of LH antiserum

In the light of the above results it was considered of interest to arrive at an MED of the LH antiserum, which would influence only the implantation process and not the survival of the implanted blastocyst. The MED was established by administration of $0.1,0.05$ and $0.025 \mathrm{ml}$ of $\mathrm{LH}$ antiserum to three groups of

TABLE 3

DELAYED IMPLANTATION WITH THE MED OF LH ANTISERUM

\begin{tabular}{|c|c|c|c|c|c|c|c|c|}
\hline \multirow[b]{3}{*}{ Group } & \multirow[b]{3}{*}{ Treatment } & \multirow{3}{*}{$\begin{array}{l}\text { No. } \\
\text { of } \\
\text { rats }\end{array}$} & \multicolumn{6}{|c|}{ Laparotomy results } \\
\hline & & & \multicolumn{2}{|c|}{$8 t h$ day } & \multicolumn{2}{|c|}{15 th day } & \multicolumn{2}{|c|}{20 th day } \\
\hline & & & $\begin{array}{l}\text { No. of } \\
\text { rats } \\
\text { with } \\
\text { sites }\end{array}$ & $\begin{array}{l}\text { No. of } \\
\text { sites } \\
\text { (totall } \\
\text { ave.) }\end{array}$ & $\begin{array}{l}\text { No. of } \\
\text { rats } \\
\text { with } \\
\text { sites }\end{array}$ & $\begin{array}{l}\text { No. of } \\
\text { sites } \\
\text { (totall } \\
\text { ave.) }\end{array}$ & $\begin{array}{l}\text { No. of } \\
\text { rats } \\
\text { with } \\
\text { sites }\end{array}$ & $\begin{array}{l}\text { No. of } \\
\text { sites } \\
\text { (total } \\
\text { ave.) }\end{array}$ \\
\hline $\begin{array}{l}\text { I } \\
\text { II } \\
\text { III }\end{array}$ & $\begin{array}{l}0.1 \mathrm{ml} \text { antiserum } \\
0.05 \mathrm{ml} \text { antiserum } \\
0.025 \mathrm{ml} \text { antiserum }\end{array}$ & $\begin{array}{l}4 \\
6 \\
2\end{array}$ & $\begin{array}{l}0 \\
1 * \\
2\end{array}$ & $\begin{array}{l}0 / 0 \\
2 / 0 \cdot 33 \\
17 / 8 \cdot 5\end{array}$ & $\begin{array}{l}0 \\
6 \\
2\end{array}$ & $\begin{array}{l}0 / 0 \\
31 / 5 \cdot 16 \\
17 / 8 \cdot 5\end{array}$ & $\begin{array}{l}0 \\
3 \dagger \\
2\end{array}$ & $\begin{array}{l}0 / 0 \\
25 / 4 \cdot 16 \\
17 / 8 \cdot 5\end{array}$ \\
\hline
\end{tabular}

* Only one rat showed two sites on 8 th day. This showed three additional sites by 20th day. $\dagger$ Three rats in this group had resorbed sites. One rat delivered normally and gave birth to seven viable pups.

rats on Day 4 of pregnancy at 10.00 hours. From the results presented in Table 3, it can be seen that $0.05 \mathrm{ml}$ was the lowest dose required to inhibit implantation. The results of the second and third laparotomy, however, showed that this dose level of antiserum only delayed implantation, a varying number of new sites appearing at these subsequent laparotomies. Not only did 
the size of the sites differ, showing that the time of implantation of viable blastocysts was different, but also the fate of implanted blastocysts in the different animals of this group varied from total to partial resorption by the 20th day, thus altering the average number of sites on this day. It may be of interest to point out here that, in rats receiving $0.025 \mathrm{ml}$ of the antiserum, though the number of implantation sites on the 8th day was normal, the size of each site was about one fourth of the normal. This, however, did not affect the continued survival of the blastocysts to term.

Mechanism of action of $L H$ : counteraction of effects of $L H$ antiserum by oestradiol-17 $\beta$

It was thought likely that administration of $\mathrm{LH}_{\mathrm{H}}$ antiserum to pregnant rats resulted in inhibition of steroid synthesis, particularly that of oestrogens. The ability of oestradiol- $17 \beta$ to counteract the inhibitory effects of $\mathbf{L H}$ antiserum was, therefore, tested by giving to one group of rats, which had already received on the 4th-day morning $0.075 \mathrm{ml}$ of $\mathbf{L H}$ antiserum, $0.25 \mu \mathrm{g}$ oestradiol-17 $\beta$ in $0.1 \mathrm{ml}$ of peanut oil, at 18.00 hours on the same day. The control group received $L H$ antiserum in the morning of the 4th day and only the oil vehicle in the evening. As seen from Table 4, oestradiol-17 $\beta$ was able to reverse the effect of LH antiserum in all the cases.

TABLE 4

REVERSAL OF LH ANTISERUM INHIBITION BY OESTRADIOL

\begin{tabular}{c|c|c|c|c}
\hline Group & Treatment & $\begin{array}{c}\text { No. } \\
\text { of } \\
\text { rats }\end{array}$ & $\begin{array}{c}\text { No. of } \\
\text { rats with } \\
\text { sites }\end{array}$ & $\begin{array}{c}\text { 8th day laparotomy: } \\
\text { No. of sites } \\
\text { (total laverage })\end{array}$ \\
\hline I & $\begin{array}{l}0.05 \mathrm{ml} \text { LH antiserum on } \\
\text { Day } 4 \text { at } 10.00 \text { hours }\end{array}$ & 5 & 0 & $0 / 0$ \\
II & $\begin{array}{l}0.075 \mathrm{ml} \text { LH antiserum } \\
\text { on Day } 4 \text { at } 10.00 \text { hours } \\
+0.25 \mu \text { g oestradiol-17 } \\
\text { at } 18.00 \text { hours }\end{array}$ & 5 & $4^{*}$ & $30 / 6 \cdot 0$ \\
\hline
\end{tabular}

* One rat bled profusely on the evening of the 7th day; its uterus was highly hyperaemic and progestational as seen at laparotomy.

\section{DISCUSSION}

It is well known that in the intact rat, pituitary is obligatory for initiating implantation. Though the earlier attempts of Schlough, Schuetz \& Meyer (1965) to induce implantation in hypophysectomized rats with ovine pituitary $\mathrm{LH}$ failed, Macdonald, Armstrong \& Greep (1967) have recently demonstrated the ability of $50 \mu \mathrm{g}$ of ovine $\mathrm{LH}$ to induce implantation when administered in a delaying agent such as bees-wax.

Using specific antigonadotrophins at different dose levels on different days, we have been able to show here, for the first time, that LH is the only pituitary gonadotrophin required for implantation in the intact rat. Hayashida \& Young 
(1963), however, in a preliminary communication, have also shown that they could inhibit implantation using a large daily dose of $2 \mathrm{ml}$ of $\mathrm{LH}$ antiserum from Days 1 to 5 of pregnancy.

Accumulated evidence suggests that both progesterone and oestrogen are essential for implantation, the former maintaining the blastocysts in a viable condition and bringing about progestational changes in the uterus, the latter being essential for the implantation process as such. Since Day 4 of pregnancy is an important marker in the normal pregnancy cycle of the rat, attention has been focused on the events occurring on that day. Shelesnyak \& Kraicer (1963), on the basis of their own and several others' work, have suggested an oestrogen surge to occur on the afternoon of Day 4 of pregnancy, which is essential for implantation on Day 6. Our observations on the effects of $\mathrm{LH}$ antiserum administered at different times on Day 4 and the reversal by oestradiol-17 $\beta$ administered on the evening of the same day, would point to an overall control of oestrogen synthesis by $\mathrm{LH}$ and that the surge is initiated before 18.00 hours of the same day.

It is not surprising that administration of large amounts of antiserum, such as $0.2 \mathrm{ml}$ in our case or $2.0 \mathrm{ml} / \mathrm{day}$, as used by Hayashida \& Young (1963), would result in total inhibition of both progesterone and oestrogen production. Thus, we have noticed that, when $0.2 \mathrm{ml}$ of antiserum is given on the evening of Day 4, though it does not result in inhibition of implantation, the implanted blastocysts are secondarily resorbed at a later date. The resorption could very well be due to lack of progesterone essential for the post-implantation survival of the blastocyst. Similarly, though administration of $0.025 \mathrm{ml}$ of antiserum on the morning of Day 4 does not result in inhibition of implantation, the implantation sites tend to be smaller in size when compared with normal ones. This decrease in size of the sites may be due to the low progesterone titres present in the antiserum-treated animals. This ability of the antiserum, when given in the large doses, to affect progesterone synthesis may well explain why Munshi \& Rao (1967) were unable to get implantation in mice treated with $0.2 \mathrm{ml}$ of $\mathrm{t} . \mathrm{H}$ antiserum and $1 \mu \mathrm{g}$ of oestradiol-17 $\beta$ on Day 3 of pregnancy.

These observations prompted us to determine the minimum effective dose of $\mathrm{LH}$ antiserum which, when given on the morning of Day 4, would essentially block oestrogen biosynthesis and not affect progesterone production to a large extent. We have thus been able to show that it is possible to delay implantation by giving as little as $0.05 \mathrm{ml}$ of $\mathrm{LH}$ antiserum on the morning of Day 4 to rats weighing 100 to $150 \mathrm{~g}$. This delayed implantation in the absence of exogenous progesterone administration would indicate the blocking, mainly, of oestrogen synthesis at this dose level.

The present investigations suggest that the oestrogen release from the ovary at mid-day on Day 4 of pregnancy is preceded by an LH surge or release from the pituitary. The fact that administration of antiserum at 10.00 hours on Day 4 of pregnancy results in total inhibition of implantation suggests that, at this time, LH has not yet stimulated oestrogen production. Using a radioimmunoassay developed in our laboratory, preliminary studies of the LH level prevailing during the evening of the 3rd day and at 10.00 hours on the 4th day show that it is significantly higher at the latter hour. 
Note added in the proof: Since different batches of antisera tend to have different antibody titres, it is essential to determine the MED with every fresh batch of antiserum used. A minimum of 360 to $450 \mu \mathrm{g}$ of $\mathrm{LH}$ specific antibody given on 4th-day morning by subcutaneous route will bring about delayed implantation.

\section{ACKNOWLEDGMENTS}

Our thanks are due to the Ford Foundation, New York, and the Indian Council of Medical Research for financial assistance and to the Endocrine Study Section, National Institutes of Health, Bethesda, Maryland, U.S.A., for a gift of $\mathbf{L H}$ and FsH. The authors are indebted to $\mathrm{Mr} \mathrm{R}$. Srinivasan for valuable technical assistance.

\section{REFERENCES}

ELY, C. A., Tuercke, R. \& Chen, B. L. (1966) Comparison of antisera to various gonadotropins as they affect the mouse vaginal cycle. Proc. Soc. exp. Biol. Med. 122, 601 .

Hayashida, T. (1962a) Inhibition of spermatogenesis and prostate development in normal rats with antiserum. Anat. Rec. 142, 308.

HAYASHIDA, T. (1962b) Immunologic studies with pituitary lactogenic hormone (prolactin). Ciba Fdn Colloq. Endocr. 14, 338.

Hayashida, T. \& Young, W. P. (1963) Interruption of pregnancy in rats with antiserum. Anat. Rec. $145,323$.

Li, G. H., Moudgal, N. R., Trenkle, A., Bourdel, G. \& Sadri, K. (1962) Some aspects of immunochemical methods of characterization of protein hormones. Ciba Fdn Colloq. Endocr. 14, 20.

Macdonald, G. J., Armstrong, D. T. \& Greep, R. O. (1967) Initiation of blastocyst implantation by luteinizing hormone. Endocrinology, 80, 172.

Madhwa RaJ, H. G., SaIRam, M. R. \& Moudgal, N. R. (1967) Role of gonadotropins in implantation: A study using specific antigonadotropins. Indian fnl exp. Biol. 5, 123.

Moudgal, N. R. \& LI, C. H. (1961) An immunochemical study of sheep pituitary interstitial cell stimulating hormone. Archs Biochem. Biophys. 95, 93.

MunshI, S. R. \& RAO, S. S. (1967) Biological specificity of antigens present in ovine luteinizing hormone. Indian Fnl exp. Biol. 5, 135.

Satram, M. R., Madhwa Raj, H. G. \& Moudgal, N. R. (1966) Presence of a gonadotropin inhibitor in the urine of the bonnet monkey, Macaca radiata. Endocrinology, 78, 923.

Satram, M. R., Madhwa Raj, H. G. \& Moudgal, N. R. (1968) Purification and properties of the FSH inhibitor obtained from urine of the monkey. F. Endocr. 40, 777.

Schlough, J. S., Schuetz, A. W. \& MeYer, R. K. (1965) Induction of implantation in the hypophysectomized rat with gonadotrophins. Proc. Soc. exp. Biol. Med. 120, 458.

Shelesnyak, M. G. \& Kraicer, P. F. (1963) The role of estrogen in nidation. In: Delayed Implantation, p. 269. Ed. A. C. Enders, University of Chicago Press.

Young, W. P., Nasser, R. \& Hayashida, T. (1963) Antiserum inhibition of the oestrous cycle in normal rats. Nature, Lond. 197, 1117. 